\title{
Employment Protection versus Flexicurity: On Technology Adoption in Unionised Firms
}

\author{
KJELL ERIK LOMMERUD \\ ODD RUNE STRAUME
}

CESIFO WORKING PAPER No. 2472

CAtegory 3: Social Protection

NOVEMBER 2008

\footnotetext{
An electronic version of the paper may be downloaded

- from the SSRN website:

- from the RePEc website:

www.SSRN.com

from the CESifo website:

www.RePEc.org

www.CESifo-group.org/wp
} 


\title{
Employment Protection versus Flexicurity: On Technology Adoption in Unionised Firms
}

\begin{abstract}
We analyse how different labour market institutions - employment protection versus flexicurity - affect technology adoption in unionised firms. We consider both trade unions' incentives to oppose or endorse labour-saving technology, and firms' incentives to invest in such technology. We find that increased flexicurity - interpreted as less employment protection and a higher reservation wage for workers - unambiguously increase firms' incentives for technology adoption, even when taking into account the response in unionised wage setting to such new technology. If we assume that unions have some direct influence over the technology to be adopted, a higher reservation wage also makes unions more willing to accept technological change. Less employment protection has the opposite effect, since this increases the downside (job losses) of labour-saving technology.
\end{abstract}

JEL Code: J51, O33.

Keywords: technology adoption, trade unions, employment protection, flexicurity.

\author{
Kjell Erik Lommerud \\ Department of Economics \\ University of Bergen \\ Postboks 7802 \\ 5020 Bergen \\ Norway \\ kjell-erik.lommerud@econ.uib.no
}

\author{
Odd Rune Straume \\ Department of Economics \\ University of Minho \\ Campus de Gualtar \\ 4710-057 Braga \\ Portugal \\ o.r.straume@eeg.uminho.pt
}

September 2008

We thank seminar participants at the Norwegian School of Economics and Business Administration, the University of Copenhagen, and the University of Nottingham, for helpful comments and suggestions. Financial support from the Norwegian Research Council is gratefully appreciated. Further, this article is part of the project How to construct Europe? 


\section{Introduction}

The rich countries of the world are similar in so many respects, but labour market relations differ quite significantly. A dividing line is often drawn between the flexible labour market of the US and the more regulated ones in Europe. Sometimes the lack of European labour market flexibility has been denoted 'eurosclerosis' (see, e.g., Bentolila and Bertola, 1990) and given as a reason why Europe lags behind the US in a time of rapid technological change and globalisation.

However, labour markets can be less than flexible in many ways, and the economic performance of European countries vary considerably. Many countries offer employment protection in various forms. This makes it costly to lay off workers, which is beneficial (at least in the shorter term) for workers who are already hired. But too strong employment protection can reduce the willingness of firms too hire people in the first place, and the work force can get stuck in old ways of production, with too little restructuring and technological and organisational change. In the longer perspective, this could hurt even the protected workforce itself.

'Flexicurity' is sometimes seen as an alternative to employment protection. Flexicurity purportedly exists in Scandinavia and the Netherlands, and the key elements are little employment protection, good unemployment insurance (and other means of income support for people outside the labour market), and an emphasis on labour market training and skill development to ease (re)entry into paid work. ${ }^{1}$

Flexicurity has become somewhat of a buzzword among policy makers. For example, the 2005 Employment Outlook (OECD, 2005) recommends countries as Germany and France to adopt a labour market model inspired by Denmark. There is also an up-start economics literature that discusses flexicurity and employment protection within formal models, something we shall return to.

The present paper is also an attempt to employ formal economic modelling to get

\footnotetext{
${ }^{1}$ Some claim that the flexicurity concept should be reserved as a description of the Danish labour market only, since Denmark has less employment protection than some other candidate countries with high unemployment insurance and active labour market policies (Andersen and Svarer, 2006).
} 
to grips with the flexicurity debate. A salient feature of the model is that workers are unionised. Those countries where authorities try to regulate the income security of workers, by employment protection, high unemployment insurance benefits, or the like, are typically countries also with other deviations from free, competitive labour markets, with trade unionism as a prime example. Trade unions are still important in most West-European economies. Membership rates may have fallen in some countries, but coverage - the number of workers covered by a union wage agreement - has fallen much less. ${ }^{2}$ The UK is perhaps the prime example of a country where unions markedly have been losing influence over the last couple of decades, but even for this country it can be asked if unions 'have turned the corner' $?^{3}$ Notice also that trade unionism remains strong in those countries that are foremostly associated with flexicurity, as the Scandinavian countries. We therefore think it is interesting to ask how regulations as employment protection and unemployment benefits interact with unionised wage setting.

'Flexibility' in the labour market is a rather vague concept that can be given many interpretations. One could perhaps delineate between 'external flexibility', which would refer to allocation and reallocation of workers among firms and sectors - and 'internal flexibility', which would concern the willingness to accept new technology, to skill upgrading and the like within the existing workplaces. In our formal model, what we think of as flexibility is the adoption of new labour-saving technologies in firms, which in this usage of language would be an example of'internal flexibility'. Within a unified framework, we take two different approaches to studying incentives for technology adoption in unionised firms. First, we consider the incentives for trade unions to oppose the implementation of (exogenously arriving) labour-saving innovations. Our starting point is the reasonable assumption that trade unions have some influence on the use of technology, and we then exaggerate this by assuming that the union can veto the adoption of any technology that is not in the best interest of the union membership. As in Dowrick and Spencer (1994) and Lommerud, Meland and Straume (2006), this is a stylised way to capture that unions

\footnotetext{
${ }^{2}$ For documentation, see OECD (1997) and EEAG (2004).

${ }^{3}$ Blanden, Machin and Van Reenen (2006).
} 
- being concerned about job losses among their members - can use their collective power to, if not permanently block, then at least significantly delay, and make more costly, the adoption of labour-saving technology. This is typically done by, e.g., refusing to concede to the changes in manning rules, remuneration systems and the like that new technology requires. ${ }^{4}$

In the second part of the analysis, we use the assumption that technology is endogenous: the firm can install labour-saving technology at a cost, but takes into account the wage response of the trade union. The influence of the union is here only indirect: it has no means to influence technology choices directly, but its influence over wage setting will possibly change technology adoption indirectly. In this part, we also analyse the firm's willingness to undertake risky investments in technology improvements.

A key question in the paper is if each of the two legs of a flexicurity policy, income protection for the unemployed or employment protection is good or bad for technology adoption. We investigate how two parameters, an employment protection variable (the cost of laying people off) and a reservation wage variable (the utility of unionised workers outside the firm in question), affect technology adoption. We interpret 'flexicurity' as an increase in the reservation wage and a decrease in employment protection. As forewarned, we are foremostly interested in how flexicurity influences adoption of labour-saving technological advances.

Our results suggest that flexicurity is unambiguously good for technology adoption if we only consider firm incentives, that is, the case where union influence only is indirect and works through the wage setting process. The increase in reservation wage and the decrease in employment protection both contribute to making the firm more willing to invest in new labour-saving technology. However, the same unambiguous conclusion cannot be reached if we focus on union incentives directly to block technology adoption. While better outside options will make unions more technology-friendly, reduced employment protection - the other leg of the flexicurity system - has the opposite effect. The reason is that employment

\footnotetext{
${ }^{4}$ See, e.g., Dowrick and Spencer (1994) and Lommerud et al. (2006) for comprehensive analyses and discussions - including many empirical and anectodal examples - of such 'rational Luddism' by trade unions.
} 
protection softens the downside of labour-saving technology, namely job losses, and therefore makes unions more willing to accept technological change. Thus, whether flexicurity is good for technological change depends on which party is more important for technology adoption in unionised economies: firms or trade unions, or put differently, to which extent unions can block or postpone the adoption of technology directly.

The flexicurity debate is often presented as a comparison of two European models. Less often is flexicurity compared with a non-interference type labour market as the US one. If one takes the existence of at least some union power as a starting point, our results suggest that non-interference is not a solution that best stimulates technology adoption. On the contrary, introducing minimum wages or social insurance that lifts the reservation wage of workers that lose their jobs - from the non-interference level - encourages technology adoption.

The pre-existing academic economics literature on the flexicurity vs. employment protection debate is small, and little focussed on technology choices, but more on issues we have dubbed 'external flexibility', such as structural change. Nevertheless, we would like to mention some related work. First we would want to point out the link to the debate in the Nordic trade union movement, spurred by the two Swedish trade union economists Gösta Rehn and Rudolf Meidner (see Turvey, 1952). They argued that it was important to keep wages up in traditional industry, to increase the rate of structural change and modernization. On the other hand, unemployment insurance and active labour market policies should be used to ease the situation for workers who lost their jobs and to speed up their re-entry into the labour market. ${ }^{5}$

One important ingredient in the flexicurity debate is unemployment insurance. Acemoglu and Shimer (2000) point out that unemployment insurance can yield productivity gains. In particular, insurance can motivate workers to move to higher productivity jobs and also motivate firms to create those jobs. Hassler and Rodriguez Mora (2008) charac-

\footnotetext{
${ }^{5}$ Agell and Lommerud (1993) and Moene and Wallerstein (1997) provide two different attempts at capturing these ideas in neoclassical economics models. Staiger (1988) provides a somewhat related model, where unions drive out the most labour-intensive production to other countries, something which enables the union to take out a higher union rent.
} 
terise optimal unemployment insurance when workers can move and/or retrain, and find that the classical result that benefits should fall with unemployment duration no longer necessarily holds. Both of the latter papers picture 'flexibility' to mean structural and geographical mobility in the labour market, in contrast to our emphasis on the installment of labour-saving technology. The other important ingredient in flexicurity is the reduction of employment protection. Bertola (2004) gives an overview of the debate on labour market institutions in Europe, with one emphasis on the consequences of employment protection. His focus is on structural change, rather than technology adoption. ${ }^{6}$

Blanchard and Tirole (2008) study the optimal design both of unemployment insurance and employment protection. In a first-best version of the model they find that unemployment insurance always should be accompanied by employment protection - and go on to discuss various deviations from this first-best model. We do not study the joint optimality of unemployment insurance and employment protection, but instead focus on the positive question how more unemployment insurance and less employment protection influence the adoption of new technology. Blanchard and Tirole do not focus on technology adoption, and trade unions are not mentioned. Algan and Cahuc (2006) postulate that the tendency to cheat on unemployment insurance programmes is larger in some countries than in others. This can make flexicurity the optimal choice for some Northern European countries, while it is not necessarily optimal to copy this policy in countries closer to the Mediterranean. ${ }^{7}$

Finally, we would like to draw attention to the relatively large literature on how trade unionism influence the technology choices of the firm. See, for example, Tauman and Weiss (1987), Ulph and Ulph (1998), Calabuig and Gonzalez-Maestre (2002) and Haucap and Wey (2004). There is no mention of flexicurity in these papers.

The rest of this paper is organised as follows. The basic model is presented in the next section. In Section 3, we analyse the labour market effects of installing new labour-saving

\footnotetext{
${ }^{6}$ Ichino and Riphahn (2005) discuss employment protection in the context of absenteeism. Dewit, Leahy and Montagna (2003) and Kessing (2006) discuss the possible strategic advantages from employment protection - building on the key insight that a firm that only costly can get rid of its workers, will fight harder to retain market shares.

${ }^{7}$ Boeri, Conde-Ruiz and Galasso (2006) bring political economy elements into the flexicurity debate.
} 
technology. In Section 4, we analyse union incentives to oppose exogenous technological change, while, in Section 5, we endogenise the technological change by analysing firm incentives for technology investments. The paper is concluded by Section 6 .

\section{Model}

In order to focus on the strategic firm-union relationship, we place the analysis in a simple dynamic framework. A unionised firm exists for two periods. In both periods, wages are set by a monopoly trade union, while employment is set by the firm. In the second period, a new labour-saving technology may or may not become available for the firm to adopt. If the new technology becomes available, the presence of employment protection legislation makes employment downsizing costly for the firm.

The firm is a monopolist in its product market, where demand is equal in both periods. The inverse demand function is given by the linear form

$$
p\left(q_{i}\right)=\alpha-\beta q_{i}
$$

where $q_{i}$ is produced quantity in period $i$. Labour is the only factor of production in a simple linear technology. Denoting employment in period $i$ by $L_{i}$, produced output in the first period is given by

$$
q_{1}=L_{1}
$$

while output in the second period is

$$
q_{2}=\left\{\begin{array}{cc}
L_{2} & \text { without new technolgy } \\
\phi L_{2} & \text { with new technology }
\end{array},\right.
$$

where $\phi>1$. Thus, the parameter $\phi$ measures the potential technological progress between the two periods. 
With the above assumptions, profits in period 1 and 2, respectively, are given by

$$
\begin{gathered}
\pi_{1}=p\left(q_{1}\right) q_{1}-w_{1} L_{1}, \\
\pi_{2}=\left\{\begin{array}{ccc}
p\left(q_{2}\right) q_{2}-w_{2} L_{2}-c\left(L_{1}-L_{2}\right) & \text { if } & L_{2}<L_{1} \\
p\left(q_{2}\right) q_{2}-w_{2} L_{2} & \text { if } & L_{2} \geq L_{1}
\end{array} .\right.
\end{gathered}
$$

The degree of employment protection is given by the parameter $c>0$, in the case of second-period downsizing of employment. ${ }^{8,9}$

Trade union objectives are given by the following Stone-Geary-type utility function for period $i$ :

$$
U_{i}=\left(w_{i}-b\right)^{\theta} L_{i}
$$

where $\theta>0$ is a measure of the degree of wage orientation in union preferences ${ }^{10}$, while $b>0$ is the reservation (reference) wage level. It is reasonable, and standard, to assume that $b$ reflects both opportunities outside the firm (e.g., the minimum wage level) and outside the labour market (e.g., unemployment benefits).

The union sets wages prior to the firm's employment decision in each of the two periods and we solve the game by backwards induction, looking for a subgame perfect Nash equilibrium in pure strategies. In the next section, we start by deriving the equilibrium outcomes of the second-period subgames (for the cases with and without technological change). Subsequently, we will provide two different approaches to analysing technological progress between the two periods. First, we assume that the arrival of the new technology is exogenous and we analyse the trade union's incentive to oppose exogenous technological change. Second, we endogenise the technological progress and analyse the firm's incentive to invest in new labour-saving technologies, but taken into account that

\footnotetext{
${ }^{8}$ We focus on the red tape component of employment protection legislation. As noted by Boeri et al. (2006), both empirical evidence (Bertola et al, 2000) and economic theory (Lazear, 1990) suggest that it is mainly red tape and procedural costs that affect employment flows.

${ }^{9}$ As pointed out by Bentolila and Bertola (1990), the effects of employment protection laws are arguably best approximated by a fixed firing cost per worker, implying linear employment downsizing costs.

${ }^{10}$ The parameter $\theta$ can indirectly be interpreted as the degree of 'insider' domination. A trade union that is more dominated by insiders will typically give more importance to wages (all else equal).
} 
technology choices influence the wage level set by the union.

\section{Labour market effects of technological change}

In this section, we derive the equilibrium outcomes of the second-period subgames and analyse how new technology affects wages and employment. There are two subgames, one where the new labour-saving technology is available and one where it is not.

\subsection{No new technology}

With the old technology, the firm has no incentive to downsize production in the second period. Maximising the second-period profit function with respect to $L_{2}$, and assuming that $L_{2} \geq L_{1}$, second-period labour demand is given by

$$
L_{2}\left(w_{2}\right)=\frac{\alpha-w_{2}}{2 \beta} .
$$

The trade union maximises its second-period utility by choosing a wage level that optimally balances the concerns for wages and employment. Inserting (7) into (6) and maximising with respect to $w_{2}$ yields ${ }^{11}$

$$
\widehat{w}_{2}=\frac{\theta \alpha+b}{1+\theta}
$$

As expected, the wage is increasing in the wage orientation of the union $(\theta)$ and in the reservation wage level $(b)$. Substituting $\widehat{w}_{2}$ into (7) yields the equilibrium employment level

$$
\widehat{L}_{2}=\frac{\alpha-b}{2 \beta(\theta+1)}
$$

\subsection{New technology}

We focus on the case of labour-saving innovations, implying that employment is downsized. Maximising the second-period profit function with respect to $L_{2}$, and assuming that $L_{2}<$

\footnotetext{
${ }^{11}$ We use "hats" to denote equilibrium second-period values in the case of no technological progress.
} 
$L_{1}$, second period labour demand is given by

$$
L_{2}\left(w_{2}\right)=\frac{\alpha \phi-w_{2}+c}{2 \beta \phi^{2}} .
$$

Naturally, given the firm's incentives for employment downsizing, the presence of employment protection $(c>0)$ makes second-period labour demand higher than it would have been in the absence of such legislation. In other words, employment protection makes second-period labour demand more inelastic, making the wage/employment trade-off more favourable for the trade union. Inserting $L_{2}\left(w_{2}\right)$ from (10) into (6) and maximising with respect to $w_{2}$ yields

$$
w_{2}^{*}=\frac{\theta(\phi \alpha+c)+b}{1+\theta} .
$$

As indicated above, stronger employment protection increases the wage level in a situation where the firm has incentives to downsize employment. Notice also that, since an increase in $\phi$ makes labour demand less responsive to wage changes,${ }^{12}$ there is a negative relationship between labour productivity and labour demand elasticity. Consequently, technological progress is accompanied by higher wages. The corresponding employment level given by

$$
L_{2}^{*}=\frac{\phi \alpha-b+c}{2 \beta \phi^{2}(\theta+1)}
$$

\section{Exogenous technological change}

Assume that the new technology arrives in the second period with an exogenous (and known) probability $\eta \in(0,1)$. Both the firm and the trade union make their first-period choices by maximising the sum of first- and (expected) second-period payoffs. For simplicity, we abstract from discounting.

\footnotetext{
${ }^{12}$ This is easily verified by observing, from (10), that the slope of the labour demand function is given by

$$
\frac{\partial L_{2}(\cdot)}{\partial w_{2}}=-\frac{1}{2 \beta \phi^{2}} .
$$
}


Expected profits over the two periods are given by

$$
\Pi=\pi_{1}+\eta \pi_{2}+(1-\eta) \widehat{\pi}_{2}
$$

Maximising this expression with respect to $L_{1}$ yields the following first-period labour demand:

$$
L_{1}\left(w_{1}\right)=\frac{\alpha-\eta c-w_{1}}{2 \beta} .
$$

Notice the negative relationship between first-period labour demand and the two parameters $\eta$ and $c$. The more likely it is that the firm wants to downsize employment in the second period, and the more costly such downsizing is, the lower is first-period labour demand. This consequently increases the wage elasticity of labour demand in the first-period.

Expected union utility over the two periods is given by

$$
V=U_{1}+\eta U_{2}+(1-\eta) \widehat{U}_{2}
$$

which, after substitution and maximisation, gives the optimal first-period wage

$$
w_{1}^{*}=\frac{\theta(\alpha-\eta c)+b}{\theta+1}
$$

with a corresponding employment level

$$
L_{1}^{*}=\frac{\alpha-b-\eta c}{2 \beta(\theta+1)}
$$

The effect of employment protection on wages and employment differs diametrically in the first and second period. Stronger employment protection implies that it is more costly for the firm to operate with a large workforce in the first period, given the incentives for second-period downsizing. Thus, stronger employment protection yields lower labour demand in the first period. In other words, the positive effect on employment in the second period is counteracted by a negative first-period effect, with a corresponding wage effect. 
This illustrates - in a very simple framework - the standard concern about the dynamic employment effects of employment protection legislation: if the cost of laying off workers is increased, this will make firms less willing to hire workers in the first place.

The above results are derived under the assumption that $L_{2}<L_{1}$ if the new laboursaving technology appears. It remains to show that this condition holds in equilibrium. Comparing (12) and (17), it can easily be shown that the condition holds if the technological progress is sufficiently large relative to downsizing costs. ${ }^{13}$ Notice also that $L_{1}^{*}<\widehat{L}_{2}$ as long as expected downsizing costs $(\eta c)$ are positive. Thus, we consider the case where $L_{2}^{*}<L_{1}^{*}<\widehat{L}_{2}$.

\subsection{Union resistance to technological change}

Will the new labour-saving technology be adopted in the second-period? Giving the trade union the power to veto any adoption of new technology, this question is answered by a comparison of second-period union utility with and without new technology. Denoting the utility gain of new technology by $\Delta U=U_{2}-\widehat{U}_{2}$, this is given by

$$
\Delta U=\frac{\theta^{\theta} \Psi}{2 \beta \phi^{2}(\theta+1)^{1+\theta}}
$$

where

$$
\Psi=(\alpha \phi-b+c)^{\theta+1}-\phi^{2}(\alpha-b)^{\theta+1} .
$$

Proposition 1 Given that the adoption of new technology leads to employment downsizing, there exists a critical value $\theta^{*}$, such that $\Delta U>(<) 0$ if $\theta>(<) \theta^{*}$.

Proof. Notice first that $\operatorname{sign}(\Delta U)=\operatorname{sign}(\Psi)$. If $\theta=0, \Psi<0$ if $L_{2}^{*}<L_{1}^{*}<\widehat{L}_{2}$ (the employment downsizing regime). Furthermore, since $\alpha \phi-b+c>\alpha-b, \Psi$ is monotonically increasing in $\theta$. Finally, since $\theta$ is not bounded from above, $\Psi>0$ for sufficiently high values of $\theta$, implying that there exists a unique value $\theta^{*}$ above (below) which $\Delta U>(<) 0$.

\footnotetext{
${ }^{13}$ More specifically, $L_{2}^{*}<L_{1}^{*}$ if $\phi>\frac{\alpha+\sqrt{\alpha^{2}-4(b-c)(\alpha-b-c \eta)}}{2(\alpha-b-c \eta)}$, or, equivalently, if $c<\frac{(\phi-1)(\phi(\alpha-b)-b)}{\eta \phi^{2}+1}$.
} 
Labour-saving innovations present the union with the following trade-off: fewer of the union members are employed by the firm, but the remaining workers can enjoy higher wages. How this trade-off is assessed depends on the union preferences for wages relative to employment. In the extreme case where the union only cares about employment $(\theta=0)$, a labour-saving innovation is always detrimental to the union, since it does not care about the wage increase that accompanies the job losses. In the other extreme case, where the union only cares about wages $(\theta \rightarrow \infty)$, a labour-saving innovation is always beneficial to the union, since it does not care about the job losses that accompany the wage increase. In general, then, the union will benefit from labour-saving innovations if it is sufficiently wage oriented. The implication for union resistance to technological change follows directly:

Corollary 1 Sufficiently employment oriented trade unions will oppose labour-saving technological change.

\subsection{Flexicurity versus employment protection}

Our main objective is to analyse how different labour market institutions affect incentives for technology adoption. When analysing union incentives, we will refer to $\theta^{*}$ as a measure of union resistance to technological change by applying the following argument: if there are many union-firm pairs in the economy and union preferences are distributed over a wide range of $\theta$, some unions will resist new technology while others will endorse it. An increase (reduction) in $\theta^{*}$ then implies that more (fewer) unions will resist technological progress, implying an overall increase in technology resistance by trade unions.

Our key labour market parameters here are $c$ and $b$. The degree of employment protection is directly given by the size of $c$, while we interpret increased flexicurity as a combination of lower $c$ and higher $b$. Doing comparative statics on the utility gain of technological change, (18), we arrive at the follwing result

Proposition 2 Union resistance to technological change will decrease due to (i) more employment protection, and/or (ii) a higher reservation wage level. 
Proof. (i) From (18) we derive $\frac{\partial(\Delta U)}{\partial c}=\frac{\theta^{\theta}(\alpha \phi-b+c)^{\theta}}{2 \beta \phi^{2}(\theta+1)^{\theta}}>0$, implying that $\frac{\partial \theta^{*}}{\partial c}<0$. (ii) From (18) we also have $\frac{\partial(\Delta U)}{\partial b}=\frac{\theta^{\theta}\left[\phi^{2}(\alpha-b)^{\theta}-(\alpha \phi-b+c)^{\theta}\right]}{2 \beta \phi^{2}(\theta+1)^{\theta}}$. Notice that, since $\alpha \phi-b+c>$ $\alpha-b, \Psi=0$ implies that $\phi^{2}(\alpha-b)^{\theta}>(\alpha \phi-b+c)^{\theta}$. Thus, $\phi^{2}(\alpha-b)^{\theta}>(\alpha \phi-b+c)^{\theta}$, implying $\frac{\partial(\Delta U)}{\partial b}>0$, at $\theta=\theta^{*}$. Consequently, $\frac{\partial \theta^{*}}{\partial b}<0$.

With respect to the effects of different labour market institutions on union opposition to technological change, we see that the picture is somewhat mixed. Increased employment protection unambiguously reduce union Luddism. ${ }^{14}$ The reason is that this type of labour market regulation reduces the downside of technological change for unionised workers, namely job losses. A policy that reduces the downside of labour-saving innovations while preserving the upside will generally make unions more technology-friendly.

However, the effect of increased flexicurity is a priori ambiguous. One leg of this policy - less employment protection - makes unions less inclined to accept new technology, while the other leg - better outside options - has the opposite effect. The positive effect of a higher reservation wage has primarily to do with the labour demand response to better technology. A higher reservation wage pushes up the union wage level, implying that that the firm will operate, all else equal, with a smaller labour stock. This makes the labour demand response to better technology more positive (or less negative), indirectly reducing the downside of labour-saving innovations for unions. ${ }^{15}$

\section{Endogenous technological change}

In the previous section we may have exaggerated the influence of the union by assuming that it could block adoption of labour-saving technology as it see fit. Here, we contrast this by presenting a model where the union has no direct influence over technology. In

\footnotetext{
${ }^{14}$ Luddism has come to refer to all sorts of opposition against new technology, but the term refers historically to the machine-breaking riots in Britain in 1811-12, which purportedly were lead by a 'General' Ludd.

${ }^{15}$ There are two counteracting effects of improved labour productivity on labour demand. On the one hand, the effective wage rate $\left(w_{2} / \phi\right)$ drops, which tends to increase labour demand. On the other hand, though, fewer workers are needed to produce a given level of output, which tends to reduce labour demand. The higher the wage elasticity of labour demand, the stronger is the former effect relative to the latter. See Dowrick and Spencer (1994) or Lommerud, Meland and Straume (2006) for a more extensive discussion.
} 
stead, the union has indirect influence over technology through the fact that the technology installed by the employer will in turn influence the wage demands of the union.

We assume that the firm can make an investment in the first period to improve the technology in the second period. We then ask how the characteristics of the labour market institutions - given by the parameters $c, b$, and $\theta$ - affect the firm's incentives to invest in better technology.

\subsection{Certain technological progress}

Assume that the firm can make an investment in the first period that yields a certain productivity $\phi>1$ in the second period. This investment will be undertaken if the (certain) payoff is sufficiently large to cover the investment costs. Since the first-period profit is independent of second-period labour productivity, the investment payoff is given by the second-period profit differential $\Delta \pi:=\pi_{2}-\widehat{\pi}_{2}$. Using the equilibrium expressions derived in Section 3, this profit gain is given by

$$
\Delta \pi=\frac{(\phi-1)(b-c)[2 \alpha \phi-(\phi+1)(b-c)]}{4 \beta \phi^{2}(\theta+1)^{2}}>0 .
$$

Naturally, the firm's incentives to invest will increase with the magnitude of $\Delta \pi$. From (19) we derive

$$
\begin{gathered}
\frac{\partial(\Delta \pi)}{\partial c}=-\frac{\partial(\Delta \pi)}{\partial b}=-\frac{(\phi-1)[\alpha \phi-(\phi+1)(b-c)]}{2 \beta \phi^{2}(\theta+1)^{2}}>0 \\
\frac{\partial(\Delta \pi)}{\partial \theta}=-\frac{(b-c)\left[b(\phi-1)(\phi+1)+c\left(3 \phi^{2}+1\right)\right]}{2 \beta \phi^{2}(\theta+1)^{3}}<0 .
\end{gathered}
$$

Notice that the positive sign of (20) is established by imposing the equilibrium restriction $L_{2}^{*}<L_{1}^{*}$.

Proposition 3 The firm's incentives to invest in better technology decreases with the degree of employment protection and the union's wage orientation, and increases with the reservation wage level. 
When unions only have indirect influence over technology choice (through the way technology influences wage setting), the relationship between labour market institutions and technology adoption is clear-cut. Both lower employment protection and better outside options for workers give the firm stronger incentives to invest in labour-saving technology. Thus, a labour market reform towards more flexicurity is unambiguously positive for technological change within this framework.

In order to understand the intuition behind these results, notice that technological progress has two opposite effects on profits. First, for a given wage and employment level, increased productivity increases output and profits. However, secondly, improved labour productivity induces a wage increase which, in terms of profits, is negative. Both of these partial effects are affected by changes in the relevant parameters: $c, b$ and $\theta$.

Changes in both employment protection and the reservation wage work indirectly through changes in the equilibrium employment level. Consider first an increase in employment protection $(c)$. This reduces second-period employment downsizing, which increases the negative profit effect of higher wages. In other words, the more costly it is for the firm to downsize employment, the less attractive it is to install a new labour-saving technology. Reduced employment downsizing also affects the direct profit gain of technological progress (for a given wage level), an effect that is generally ambiguous. However, the first effect always dominates, reducing the profitability of technological progress for the firm.

The effect of a higher reservation wage level is quantitatively similar, but with an opposite sign. A higher reservation wage pushes up the wage level, leading to a smaller labour stock, which reduces the negative profit effect of a (technology-induced) wage increase. The effects are thus exactly opposite to an increase in employment protection: the profitability of technological progress increases in $b$.

A more wage oriented union, on the other hand, reduces the profitability of technological progress. An increase in wage orientation $(\theta)$ pushes up the wage level and therefore reduces employment. On the one hand, lower employment reduces the profit loss of higher 
wages. However, on the other hand, the wage response is stronger. It is easily seen from (11) that a more wage oriented union will enforce a larger wage increase following a technological progress. Lower employment also affects the direct profit gain from increased productivity of the workforce. As previously mentioned, this effect is, in general, ambiguous. In sum, though, the overall effect of a more wage oriented union is always negative with respect to the profit effect of technological progress. This result clearly resembles the well-known results by Grout (1984) and Manning (1987) about the investment-deterring effects of trade unions.

Finally, notice that more wage oriented unions will reduce union opposition to technological change, but at the same time reduce firm incentives for technology investments.

\subsection{Uncertain technological progress}

In addition to the investment that yields a second-period productivity $\phi$, assume that the firm has also a risky investment option in the first period. The risky technology investment yields a second-period productivity $\mu>\phi$, but only with a probability $\rho<1$. How does the labour market characteristics affect the firm's propensity to opt for the risky technology investment?

Once more, only (expected) second-period profits matter. The payoff from the safe investment option is given by $\pi_{2}(\phi)$, while the expected payoff from the risky investment is given by $\rho \pi_{2}(\mu)+(1-\rho) \widehat{\pi}_{2}$. Assume that both investments are equally costly. Since $\mu>\phi$, and since second-period profits are increasing in labour productivity, the firm will choose the risky investment if $\rho$ is sufficiently high. We can thus define a threshold value of $\rho$ for which both investment options are equally profitable. This value, denoted $\rho^{*}$, is given by

$$
\rho^{*}=\frac{\mu^{2}(\phi-1)\left[b(\phi-1)(\phi+1)+c\left(3 \phi^{2}+1\right)\right]}{\phi(\mu-1)\left[(\mu(\phi-2)-\phi(\phi-1))(b-c)+\mu \phi^{2}(b+3 c)\right]} .
$$

It follows that the firm will choose the risky investment if $\rho>\rho^{*}$ and the safe investment otherwise. Thus, for given levels of $\mu$ and $\phi$, we can interpret $\rho^{*}$ as an inverse measure of the firm's willingness to take risks. The comparative statics results follow straightforwardly 
from (22):

$$
\begin{gathered}
\frac{\partial \rho^{*}}{\partial c}=-\frac{\partial \rho^{*}}{\partial b}=\frac{2 \mu^{2}(\phi-1)^{2}(\mu-\phi)\left[b(\phi-1)(\phi+1)+c\left(\phi^{2}+1\right)\right]}{\phi(\mu-1)\left((\mu(\phi-2)-\phi(\phi-1))(b-c)+\mu \phi^{2}(b+3 c)\right)^{2}}>0, \\
\frac{\partial \rho^{*}}{\partial \theta}=0 .
\end{gathered}
$$

Proposition 4 The firm's willingness to undertake risky technology investments is decreasing in the degree of employment protection, increasing in the reservation wage level, and is independent of union preferences.

Due to decreasing marginal revenues, the profit function is concave in labour productivity. Stronger employment protection shifts down the profit curve and also makes it more concave, since it is more costly for the firm to optimally adjust the labour stock in response to technological progress. This makes the firm less willing to invest in risky technology. A higher reservation wage, on the other hand, also shifts down the profit curve but makes it less concave, since the marginal profit gain of higher labour productivity increases with the wage level. Thus, a higher reservation wage makes the firm more willing to invest in risky technology.

When seen in conjunction with Proposition 3, it appears that a reduction in employment protection and/or an increase in union reservation wages do not only increase the firm's incentives to invest in better technology, it also makes the firm more willing to take risks, implying a higher expected technological progress.

\section{Concluding remarks}

Recent opinion polls indicate that workers in the Nordic countries fear globalisation less than workers in other rich countries. ${ }^{16}$ This could of course stem from the fact that they are better insured against adverse events in the labour markets. But in addition the flexicurity type labour market arrangements in these countries can have paved the

\footnotetext{
${ }^{16}$ Scheve and Slaughter (2006).
} 
way for structural change and technological improvements. In turn, this could mean that the bulk of Nordic workers now have high productivity jobs that are less challenged by globalisation than jobs with less technology content. Annenkov and Madaschi (2005) document that since the mid-1990s the Nordic EU countries have experienced stronger labour productivity growth than the larger EU countries. They claim that innovation and technological changes lie behind this fact. Flexicurity is of course only one element in the social model that has produced this outcome, but perhaps an important one. It is beyond the scope of this paper to try to disentangle why adoption of new technology has been so rapid in Northern Europe. Rather, the purpose of this paper has been to contribute to this debate by carefully analysing the effect of social insurance and employment protection on trade union behaviour, on wages and employment in the industry in question, and on the union's willingness to accept new technology. The basic flavour of our results is a confirmation that flexicurity is good for change. Notably, trade unionism is important for this result. The employer side is typically willing to install labour-saving technology. Organised workers can be harder to persuade. Flexicurity can be important because it contributes to build down that barrier to technology adoption that trade unions can represent.

Flexicurity is a two-legged policy, with reduced employment protection and a better situation for laid-off workers as the two legs. Of course, the flexicurity package can be unbundled, and the separate parts can be introduced separately. This paper is not meant to contain a full cost-benefit analysis of the two policy instruments involveld. However, we have hinted that better outside options for laid-off workers is the instrument than most clearly takes care of the 'flexibility' part of 'flexicurity'. Both firms and unions get to be more willing to accept labour-saving technology change when outside options are good. Building down employment protection may be good because employers dare to hire more people for any given level of technology. Its role to promote more flexible views towards technological change, though, can less be taken for granted. If workers through their union has strong direct influence over technology adoption, they would be more inclined to veto 
labour-saving innovations when employment protection is bad, simply because laboursaving technology in that case would imply more job losses. This conclusion is changed if workers only have an indirect influence over technology, through the way technology influences wage demands. Firms like labour-saving more the less employment protection there is, because then they have a chnace to get more out of a costly investment that is meant to reduce the number of employees. Unions on their side will in this case increase the wage they set, but this will not be sufficient to overturn the conclusion that also lower employment protection leads to more adoption of labour-saving technology. So when union influence over technology is indirect in this sense, both legs of a flexicurity package is good for technology adoption. A further result is that with indirect union influence, firms will not only want to invest more in labour-saving technology as employment protection gets more lax, they will also be willing to accept more risks when seeking labour-saving opportnities.

\section{References}

[1] Acemoglu, D., Shimer, R., 2000. Productivity gains from unemployment insurance. European Economic Review, 44, 1195-1224.

[2] Agell, J., Lommerud, K.E., 1993. Egalitarianism and growth. Scandinavian Journal of Economics, 95, 559-579.

[3] Algan, Y., Cahuc, P., 2006. Civic attitudes and the design of labor market institutions: which countries can implement the Danish flexicurity model? IZA Discussion Paper No 1928.

[4] Annenkov, A., Madaschi, C., 2005. Labour productivity in the Nordic EU countries. A comparative overview and explanatory factors 1980-2004. European Central Bank Occasional Paper No. 39. 
[5] Andersen, T.M., Svarer, M., 2006. Flexicurity - den danske arbejdsmarkedsmodellen. Ekonomisk Debatt 34 (1), 17-29.

[6] Bertola, G., 2004. National labor market institutions and the European integration process. CESifo Economic Studies, 50, 279-298.

[7] Bertola, G., Boeri, T., Cazes, S., 2000. Employment protection in industrialized countries: the case for new indicators. International Labour Review, 139, 57-72.

[8] Bentolila, S., Bertola, G., 1990. Firing costs and labor demand: How bad is Eurosclerosis? Review of Economic Studies, 57, 381-402.

[9] Blanchard, O., Tirole, J., 2008. The joint design of unemployment insurance and employment design. Journal of the European Economic Association, 6, 45-77.

[10] Blanden, J., Machin, S., Van Reenen, J., 2006. Have unions turned the corner? New evidence on recent trends in union recognition in UK firms. British Journal of Industrial Relations, 44, 169-190.

[11] Boeri, T., Conde-Ruiz, J.I., Galasso, V., 2006. The political economy of flexicurity. Working Papers 2006-15, FEDEA.

[12] Calabuig, V., Gonzalez-Maestre, M., 2002. Union structure and incentives for innovation. European Journal of Political Economy, 18, 177-192.

[13] Dewit, G., Leahy, D., Montagna, C., 2003. Employment Protection and Globalisation in Dynamic Oligopoly. University of Dundee Discussion Paper No. 137.

[14] Dowrick, S., Spencer, B., 1994. Union attitudes to labour-saving innovations: When are unions Luddites? Journal of Labor Economics, 12, 316-344.

[15] EEAG (European Economic Advisory Group), 2004. Report on the European economy 2004. Munich: CESifo.

[16] Grout, P.A., 1984. Investment and wages in the absence of binding contracts - a Nash bargaining approach. Econometrica, 52, 449-460. 
[17] Hassler, J., Rodriguez Mora, J.V., 2008. Unemployment insurance design: Inducing moving and retraining. European Economic Review, 52, 757-791.

[18] Haucaup, J., Wey, C., 2004. Unionisation structures and innovation incentives. Economic Journal, 114, C149-C165.

[19] Ichino, A, Riphahn, R.T., 2005. The effect of employment protection on worker effort - a comparison of absenteeism during and after probation. Journal of the European Economic Association, 3, 120-143.

[20] Kessing, S., 2006. Employment protection and product market competition. Scandinavian Journal of Economics, 108, 339-352.

[21] Lazear, E., 1990. Job security provisions and employment. Quarterly Journal of Economics, 105, 699-726.

[22] Lommerud, K.E., Meland, F., Straume, O.R., 2006. Globalisation and union opposition to technological change. Journal of International Economics, 68, 1-23.

[23] Manning, A., 1987. An integration of trade-union models in a sequential bargaining framework. Economic Journal, 97, 121-139.

[24] Moene, K.O., Wallerstein, M., 1997. Pay inequality. Journal of Labor Economics, 15, 403-430.

[25] OECD, 1997. Economic perofrmance and the structure of collective bargaining. In OECD Employment Outlook 1997. Paris: OECD.

[26] OECD, 2005. Employment Outlook 2005. Paris: OECD.

[27] Oswald, A., 1985. The economic theory of trade unions: an introductory survey. Scandinavian Journal of Economics, 87, 160-193.

[28] Scheve, K., Slaughter, M., 2006. Public opinion, international economic integration, and the welfare state. In P. Bardhan, S. Bowles and M. Wallerstein (eds.): Globalization and egalitarian redistribution. Princeton University Press. 
[29] Staiger, R., 1988. Organized labor and the scope of international specialization. Journal of Political Economy, 96, 1022-1047.

[30] Tauman, Y., Weiss, Y., 1987. Labour unions and the adoption of new technology. Journal of Labor Economics, 5, 477-501.

[31] Turvey, R., (ed.), 1952. Wages policy under full employment. London: William Hodge and Company.

[32] Ulph, A., Ulph, D., 1998. Labour markets, bargaining and innovation. European Economic Review, 42, 931-939. 


\section{CESifo Working Paper Series}

for full list see www.cesifo-group.org/wp

(address: Poschingerstr. 5, 81679 Munich, Germany, office@cesifo.de)

2413 Thorsten Upmann, Labour Unions - To Unite or to Separate?, October 2008

2414 Sascha O. Becker and Ludger Woessmann, Luther and the Girls: Religious Denomination and the Female Education Gap in $19^{\text {th }}$ Century Prussia, October 2008

2415 Florian Englmaier and Stephen Leider, Contractual and Organizational Structure with Reciprocal Agents, October 2008

2416 Vittorio Daniele and Ugo Marani, Organized Crime and Foreign Direct Investment: The Italian Case, October 2008

2417 Valentina Bosetti, Carlo Carraro, Alessandra Sgobbi and Massimo Tavoni, Modelling Economic Impacts of Alternative International Climate Policy Architectures. A Quantitative and Comparative Assessment of Architectures for Agreement, October 2008

2418 Paul De Grauwe, Animal Spirits and Monetary Policy, October 2008

2419 Guglielmo Maria Caporale, Christophe Rault, Robert Sova and Anamaria Sova, On the Bilateral Trade Effects of Free Trade Agreements between the EU-15 and the CEEC-4 Countries, October 2008

2420 Yin-Wong Cheung and Daniel Friedman, Speculative Attacks: A Laboratory Study in Continuous Time, October 2008

2421 Kamila Fialová and Ondřej Schneider, Labour Market Institutions and their Effect on Labour Market Performance in the New EU Member Countries, October 2008

2422 Alexander Ludwig and Michael Reiter, Sharing Demographic Risk - Who is Afraid of the Baby Bust?, October 2008

2423 Doina Maria Radulescu and Michael Stimmelmayr, The Welfare Loss from Differential Taxation of Sectors in Germany, October 2008

2424 Nikolaus Wolf, Was Germany ever United? Evidence from Intra- and International Trade 1885 - 1933, October 2008

2425 Bruno S. Frey, David A. Savage and Benno Torgler, Noblesse Oblige? Determinants of Survival in a Life and Death Situation, October 2008

2426 Giovanni Facchini, Peri Silva and Gerald Willmann, The Customs Union Issue: Why do we Observe so few of them?, October 2008 
2427 Wido Geis, Silke Uebelmesser and Martin Werding, Why go to France or Germany, if you could as well go to the UK or the US? Selective Features of Immigration to four major OECD Countries, October 2008

2428 Geeta Kingdon and Francis Teal, Teacher Unions, Teacher Pay and Student Performance in India: A Pupil Fixed Effects Approach, October 2008

2429 Andreas Haufler and Marco Runkel, Firms' Financial Choices and Thin Capitalization Rules under Corporate Tax Competition, October 2008

2430 Matz Dahlberg, Heléne Lundqvist and Eva Mörk, Intergovernmental Grants and Bureaucratic Power, October 2008

2431 Alfons J. Weichenrieder and Tina Klautke, Taxes and the Efficiency Costs of Capital Distortions, October 2008

2432 Andreas Knabe and Ronnie Schöb, Minimum Wage Incidence: The Case for Germany, October 2008

2433 Kurt R. Brekke and Odd Rune Straume, Pharmaceutical Patents: Incentives for R\&D or Marketing?, October 2008

2434 Scott Alan Carson, Geography, Insolation, and Institutional Change in $19^{\text {th }}$ Century African-American and White Stature in Southern States, October 2008

2435 Emilia Del Bono and Daniela Vuri, Job Mobility and the Gender Wage Gap in Italy, October 2008

2436 Marco Angrisani, Antonio Guarino, Steffen Huck and Nathan Larson, No-Trade in the Laboratory, October 2008

2437 Josse Delfgaauw and Robert Dur, Managerial Talent, Motivation, and Self-Selection into Public Management, October 2008

2438 Christian Bauer and Wolfgang Buchholz, How Changing Prudence and Risk Aversion Affect Optimal Saving, October 2008

2439 Erich Battistin, Clara Graziano and Bruno Parigi, Connections and Performance in Bankers' Turnover: Better Wed over the Mixen than over the Moor, October 2008

2440 Erkki Koskela and Panu Poutvaara, Flexible Outsourcing and the Impacts of Labour Taxation in European Welfare States, October 2008

2441 Marcelo Resende, Concentration and Market Size: Lower Bound Estimates for the Brazilian Industry, October 2008

2442 Giandomenico Piluso and Roberto Ricciuti, Fiscal Policy and the Banking System in Italy. Have Taxes, Public Spending and Banks been Procyclical in the Long-Run? October 2008 
2443 Bruno S. Frey and Katja Rost, Do Rankings Reflect Research Quality?, October 2008

2444 Guglielmo Maria Caporale, Antoaneta Serguieva and Hao Wu, Financial Contagion: Evolutionary Optimisation of a Multinational Agent-Based Model, October 2008

2445 Valentina Bosetti, Carlo Carraro and Massimo Tavoni, Delayed Participation of Developing Countries to Climate Agreements: Should Action in the EU and US be Postponed?, October 2008

2446 Alexander Kovalenkov and Xavier Vives, Competitive Rational Expectations Equilibria without Apology, November 2008

2447 Thiess Buettner and Fédéric Holm-Hadulla, Cities in Fiscal Equalization, November 2008

2448 Harry H. Kelejian and Ingmar R. Prucha, Specification and Estimation of Spatial Autoregressive Models with Autoregressive and Heteroskedastic Disturbances, November 2008

2449 Jan Bouckaert, Hans Degryse and Thomas Provoost, Enhancing Market Power by Reducing Switching Costs, November 2008

2450 Frank Heinemann, Escaping from a Combination of Liquidity Trap and Credit Crunch, November 2008

2451 Dan Anderberg, Optimal Policy and the Risk Properties of Human Capital Reconsidered, November 2008

2452 Christian Keuschnigg and Evelyn Ribi, Outsourcing, Unemployment and Welfare Policy, November 2008

2453 Bernd Theilen, Market Competition and Lower Tier Incentives, November 2008

2454 Ondřej Schneider, Voting in the European Union - Central Europe's Lost Voice, November 2008

2455 Oliver Lorz and Gerald Willmann, Enlargement versus Deepening: The Trade-off Facing Economic Unions, November 2008

2456 Alfons J. Weichenrieder and Helen Windischbauer, Thin-Capitalization Rules and Company Responses, Experience from German Legislation, November 2008

2457 Andreas Knabe and Steffen Rätzel, Scarring or Scaring? The Psychological Impact of Past Unemployment and Future Unemployment Risk, November 2008

2458 John Whalley and Sean Walsh, Bringing the Copenhagen Global Climate Change Negotiations to Conclusion, November 2008

2459 Daniel Mejía, The War on Illegal Drugs in Producer and Consumer Countries: A Simple Analytical Framework, November 2008 
2460 Carola Frydman, Learning from the Past: Trends in Executive Compensation over the Twentieth Century, November 2008

2461 Wolfgang Ochel, The Political Economy of Two-tier Reforms of Employment Protection in Europe, November 2008

2462 Peter Egger and Doina Maria Radulescu, The Influence of Labor Taxes on the Migration of Skilled Workers, November 2008

2463 Oliver Falck, Stephan Heblich and Stefan Kipar, The Extension of Clusters: Differencein-Differences Evidence from the Bavarian State-Wide Cluster Policy, November 2008

2464 Lei Yang and Keith E. Maskus, Intellectual Property Rights, Technology Transfer and Exports in Developing Countries, November 2008

2465 Claudia M. Buch, The Great Risk Shift? Income Volatility in an International Perspective, November 2008

2466 Walter H. Fisher and Ben J. Heijdra, Growth and the Ageing Joneses, November 2008

2467 Louis Eeckhoudt, Harris Schlesinger and Ilia Tsetlin, Apportioning of Risks via Stochastic Dominance, November 2008

2468 Elin Halvorsen and Thor O. Thoresen, Parents' Desire to Make Equal Inter Vivos Transfers, November 2008

2469 Anna Montén and Marcel Thum, Ageing Municipalities, Gerontocracy and Fiscal Competition, November 2008

2470 Volker Meier and Matthias Wrede, Reducing the Excess Burden of Subsidizing the Stork: Joint Taxation, Individual Taxation, and Family Splitting, November 2008

2471 Gunther Schnabl and Christina Ziegler, Exchange Rate Regime and Wage Determination in Central and Eastern Europe, November 2008

2472 Kjell Erik Lommerud and Odd Rune Straume, Employment Protection versus Flexicurity: On Technology Adoption in Unionised Firms, November 2008 